\title{
KONSEP RAMAH LINGKUNGAN DALAM PERSPEKTIF ALQURAN, HADIS, DAN KITAB KUNING DI PESANTREN
}

\author{
Rustam Ibrahim', A. Mufrod Teguh Mulyo², Lilis Fatimah³ \\ 1,2,3 Universitas Nahdatul Ulama (UNU) Surakarta \\ Jl. Dr. Wahidin No.5 Penumping, Laweyan, Kota Surakarta, Jawa Tengah \\ E-mail: rustam_ibrahim85@yahoo.co.id
}

\begin{abstract}
The Concept of environmentally-friendly in the Quran, Hadith, and Kitab Kuning in Pesantren. Environmental problems in Indonesia are worrying condition indicated by forest fires, landslide calamities, and floods in various parts of Indonesia. It informed that Indonesia is experiencing an environmental crisis. Pesantren as an Islamic educational institution has great potential in socializing environmentally-friendly concept in society. There are 27,218 pesantren[s] with 3,642,738 santri[s], located in rural areas, farms and mountains. This showed that pesantren has potential as a locomotive in environmental conservation. References of santri are Quran, hadith, and kitab kuning. The question is whether there is an environmentally-friendly concept in the Quran, hadith, and kitab kuning of pesantren, so it can be the guidance of santri in maintaining the environment. This research focuses on the concept, formulation, and urgency of environment in the perspective of Quran, hadith, and kitab kuning. The method used in this research is library research. Based on the research, there is a concept of environmentally-friendly in the Quran, hadith, and pesantren's kitab kuning, that is, the obligation to maintain the environment. The formulation of environmentally-friendly concepts is a recommendation to maintain cleanliness, utilize empty land to be productive, greening spirits, create conservation areas, hard restrictions to pollute the environment, and severe sanctions for environmental destruction.
\end{abstract}

Keywords: concept of environmentally-friendly; the Quran; hadith; kitab kuning of pesantren.

\begin{abstract}
Abstrak: Konsep Ramah Lingkungan dalam Perspektif Alquran, Hadis, dan Kitab Kuning di Pesantren. Permasalahan lingkungan yang terjadi di Indonesia sudah sangat mengkhawatirkan. Indikasinya adalah sering terjadi kebakaran hutan, musibah tanah longsor, dan musibah banjir yang hamper menjadi langganan setiap tahun di berbagai daerah di Indonesia. Hal tersebut memberitahukan bahwa Indonesia sedang mengalami krisis lingkungan. Pesantren sebagai lembaga pendidikan Islam di Indonesia memiliki potensi besar dalam mensosialisasikan konsep ramah lingkungan di masyarakat. Jumlah pesantren sebanyak 27.218 pesantren dengan jumlah santri sebanyak 3.642.738 jiwa. Kebanyakan pesantren berlokasi di pedesaan, pertanian dan pegunungan. Hal ini menunjukkan bahwa pesantren berpotensi sebagai lokomotif dalam konservasi lingkungan. Rujukan santri pesantren adalah Alquran, hadis, dan kitab kuning, termasuk dalam menjaga lingkungan. Pertanyaannya adalah apakah terdapat konsep ramah lingkungan dalam Alquran, hadis, dan kitab kuning di pesantren. Sehingga dapat menjadi pedoman santri dalam menjaga lingkungan. Penelitian ini fokus terhadap konsep, formulasi, dan urgensi ramah lingkungan dalam perspektif Alqutan, hadis, dan kitab kuning pesantren. Metode yang digunakan dalam penelitian ini adalah library research. Berdasarkan penelitian, terdapat konsep tentang ramah lingkungan dalam Alquran, hadis, dan kitab kuning pesantren, yaitu kewajiban untuk menjaga lingkungan. Formulasi konsep ramah lingkungan adalah anjuran menjaga kebersihan, memanfaatkan lahan kosong menjadi produktif, semangat penghijauan, membuat kawasan konservasi, larangan keras mencemari lingkungan, dan sanksi berat bagi perusak lingkungan.
\end{abstract}

Kata kunci: konsep ramah lingkungan; Alquran; hadis; kitab kuning; pesantren.

\section{Pendahuluan}

Permasalahan lingkungan yang terjadi di Indonesia sudah sangat mengkhawatirkan, indikasinya adalah sering terjadi kebakaran hutan yang hampir menjadi langganan setiap tahun di Kalimantan dan Sumatera. Selain itu, musibah tanah longsor juga sering terjadi di Ponorogo, Banjarnegara, Semarang, Magelang, dan daerah lain. Indikasi lainnya, musibah banjir sering melanda beberapa wilayah di Bojonegoro, 
Lamongan, Bandung, Surakarta, dan daerah lainnya. Beberapa hal di atas memberitahukan bahwa Indonesia sedang mengalami krisis masalah lingkungan.

Para ilmuwan telah mendokumentasikan bahwa kita hidup di tengah ancaman kepunahan periode keenam, yang diindikasikan oleh banyaknya spesies yang punah pertahun. Sekarang ini, dinyatakan lebih dari 10.000 spesies punah setiap tahun. Oleh sebab itu, menjaga lingkungan semakin disadari nilai pentingnya. Kesadaran itu muncul setelah dirasakan adanya keterkaitan erat antara lingkungan dengan hari depan kehidupan bumi. Kerusakan di mana-mana ditimbulkan oleh perlakuan semena-mena terhadap alam lingkungan'.

Krisis lingkungan memerlukan kesadaran dan kepedulian dari segenap masyarakat. Indonesia dengan negara berpenduduk muslim terbesar di dunia. Kebanyakan pemeluknya tersebar di setiap pelosok, dari perkotaan hingga hutan dan pegunungan, yang berdekatan dengan kawasan konservasi dan taman nasional. Salah satu komunitas utama masyarakat Islam Indonesia adalah pesantren yang memiliki peran penting dalam mensosialisasikan pentingnya konservasi alam dan lingkungan. Islam sebagai agama yang membawa rahmat untuk alam semesta (rahmatan lil 'alamin) memiliki kearifan yang bersumber dari Alquran dan hadis. Berdasarkan kedua sumber hukum tersebut, para ulama merumuskan ilmu pengetahuan yang diwariskan hingga kini berupa kitab klasik (kitab kuning) yang mengandung rumusan terkait pelestarian lingkungan².

Menurut catatan Bagian Perencanaan dan Sistem Informasi Sekretariat Ditjen Pendidikan Islam Kementerian Agama RI, pada tahun 2010/2011 terdapat 27.218 buah pesantren di seluruh Indonesia dengan jumlah santri sebanyak 3.642 .738 jiwa $^{3}$. Luasnya sebaran pondok

\footnotetext{
${ }^{1}$ Hasbi Umar, Nalar Fiqih Kontemporer (Jakarta: GP Press, 2007), h.211.

2 Ahsin Sakho Muhammad dkk (Ed), Fikih Lingkungan, Laporan Indonesia Forest and Media Campaign (Inform): Pertemuan Menggagas Fikih Lingkungan oleh Ulama Pesantren di Lido Sukabumi, 9-12 Mei 2014. 2

3 Nursyam, Buku Saku Bagian Perencanaan dan Sistem Informasi Sekretariat Ditjen Pendidikan Islam Kementerian Agama RI tahun 2010/2011 ( Jakarta: Kementerian Agama RI), 30.
}

pesantren juga merupakan hal yang menarik. Penelitian yang dilakukan oleh EMIS (Education Management Information System $)^{4}$ sejak tahun 2001 melaporkan bahwa 8.829 pesantren berada di daerah pedesaan. Selebihnya, jika ditinjau berdasarkan lokasinya, 2.429 pesantren berlokasi di daerah pertanian dan 1.546 di daerah pegunungan. Sekitar $50 \%$ pesantren berada di lokasi daerah permukiman. Kondisi ini menunjukkan bahwa pesantren berpotensi sebagi lokomotif bagi penularan kesadaran konservasi dan pembangunan di desa5.

Dengan jumlah santri yang besar dan didukung dengan letak geografisnya yang dekat dengan lingkungan masyarakat pedesaan, maka pesantren memiliki potensi yang besar dalam mensosialisasikan kesadaran konservasi lingkungan. Pesantren dalam setiap langkahnya, termasuk dalam konsep ramah lingkungan, selalu mengacu pada literatur yang khas, yaitu Alquran, hadis, dan kitab kuning. Martin Van Bruinessen menyebut kitab kuning, sebagai "great tradition" dalam pengajaran agama, yaitu transmisi Islam tradisional dalam kitab kuning yang telah ditulis oleh ulama berabad-abad yang lalu'. Kitab kuning merupakan "ruh" dalam kurikulum pesantren. Bahkan bisa dikatakan, lembaga pendidikan belum sah disebut pesantren tanpa keberadaan Alquran, hadis, dan kitab kuning di dalamnya7. Zamakhsyari Dhofier ${ }^{8}$ menyebut kitab kuning sebagai salah satu rukun yang wajib ada di dalam pesantren. Atau meminjam istilah Abdurrahman Wahid, kitab kuning merupakan salah satu sistem

4 EMIS merupakan pusat pendataan Pendidikan Islam (satu pintu) yang berperan dalam menunjang proses perencanaan dan pengambilan kebijakan program Pendis, baik Madrasah, PAI juga pendidikan non formal Pendidikan Diniyah dan Pondok Pesantren. Lihat. http://www.jateng. kemenag.go.id/berita/integrasi-data-emis-tingkatkan-mutupengelolaan-data/, diakses tanggal 24 Agustus 2017. Lihat juga, Nursyam, Buku Saku Bagian Perencanaan dan Sistem Informasi Sekretariat Ditjen Pendidikan Islam Kementerian Agama RI tahun 2010/2011 ( Jakarta: Kementerian Agama RI), h. 30.

${ }^{5}$ Nursyam, Buku Saku Bagian Perencanaan..., h. 31

6 Martin Van Bruinessen, Kitab Kuning: Pesantren dan Tarekat (Bandung: Mizan, 1994), h.17.

7 Rustam Ibrahim, Bertahan di Tengah Perubahan: Pesantren Salaf, Kiai, dan Kitab Kuning, (Jogjakarta: Sibuku kerjasama dengan UNU Surakarta, 2015), h. 74.

8 Dhofier, Zamakhsari. Tradisi Pesantren: Studi Tentang Pandangan Hidup Kyai, (Jakarta: LP3ES, 1983). 50. 
nilai dalam kehidupan pesantren. Kitab kuning adalah landasan normatif dalam bertindak dan berperilaku, baik bagi kiai, keluarga kiai, pengurus pesantren, santri, dan alumni' ${ }^{10}$.

Referensi yang digunakan dalam penelitian ini menggunakan sumber utama agama Islam, yaitu Alquran, kemudian menggunakan kitabkitab hadis dan kitab kuning. Kitab kuning yang dipakai di antaranya tafsir Alquran, seperti Kitab Tafsîr al-Qur'ân Jamî'ul Bayân fî Ta'wîl al-Qur'ân karya Syekh Muhammad Ibnu Jarir At Thobari, Tafsîr Ibnu Katsîr karya Syekh Abu al-Fida' Ismail bin Umar bin Katsîr, dan Tafsîr al-Matûridî karya Imam Abu Manshur Al-Matûridî. Kitab Hadis mengacu pada kitab Musnad Imâm Ahmad bin Hanbal karya Imâm Ahmad bin Hanbal, kitab Fathul Bârî Syarah Shahîh Bukhârî karya Imâm Ibnu Hajar Al-Asqalani dan Kitab Al Minhâj Syarah Shahîh Muslim karya Imâm An Nawawî. Kitab fikih mengacu kitab Hasyiyah al-Bujairimiy 'Ala al-Khatib karya Sulaiman bin Muhammad Al-Bujairomi. Fikih Jinayat mengacu pada Tasyri' al Jana'î dan alAhkâm al-Sulthâniyyah karya Imam al-Mawardi. Kitab Ushul Fikih mengacu pada kitab Qowâ'idul Ahkâm karya Syekh Izzuddin bin Abdissalam dan kitab al-Wajiz fî Ushûl al-Fiqhi karya Syekh Abdul Karîm Zidan.

Kitab-kitab di atas tentunya telah merumuskan nilai-nilai yang terkait dengan isu lingkungan hidup dan konservasi alam, karena itu penulis tertarik untuk menggali khazanah pandangan Islam dari sumber-sumbernya. Terutama terkait unsur-unsur yang berkaitan dengan pemeliharaan alam dan lingkungan dalam Islam sesuai dengan Alquran, hadis, dan kitab kuning di pesantren. Penelitian ini memaparkan bagaimana konsep ramah lingkungan dalam perspektif Alquran, hadis, dan kitab kuning di pesantren. Selanjutnya secara khusus memaparkan bagaimana aplikasi dan filosofi konsep ramah lingkungan dalam perspektif Alquran, hadis, dan kitab kuning di pesantren.

Dalam artikel ini penulis menggunakan teori Othman Llewelyn yang menyatakan bahwa Islam adalah agama peduli lingkungan. Banyak teks

9 Abdurrahman Wahid, "Asal-Usul Tradisi Keilmuan di Pesantren”, Jurnal Pesantren, 1 (Januari,1984), h. 7.

${ }^{10}$ Rustam Ibrahim, Bertahan..., h. 74. yang memerintahkan manusia untuk menjaga lingkungannya untuk kemaslahatan bersama. Konsep menjaga lingkungan dan alam menyatu dengan konsep tauhid, syariah, dan akhlak, sehingga teori ini penting karena agama menjadi sumber yang efektif bagi konservasi lingkungan". Selain itu, agama juga menjadi rem yang ampuh bagi manusia agar tidak merusak lingkungan. Agama sangat diharapkan perannya dalam mengantisipasi kerusakan lingkungan ketika jalur sains dan jalur birokrasi terhambat. Agama diharapkan dapat mempengaruhi jiwa dan mental manusia agar tidak merusak ekosistem lingkungan ${ }^{12}$.

\section{Metode Penelitian}

Penelitian ini memakai metode library research, sebuah penelitian kepustakaan. ${ }^{13}$ Penelitian kepustakaan adalah penelitian terhadap ajaran yang hubungannya dengan masyarakat, sifat-sifat, watak, pengaruh pemikiran dan idenya serta membentuk watak kelompok masyarakat, penelitian ini masuk dalam kategori penelitian pustaka. ${ }^{14}$ Metode ini untuk mendapatkan data tentang konsep ramah lingkungan dalam Alquran, hadis, dan kitab kuning di pesantren dengan pendekatan deskriptif.

Penelitian ini juga bisa disebut studi naskah. Studi ini bertujuan untuk membuat rekonstruksi teks secara obyektif dan teratur dengan jalan menyusun, mengevaluasi, memverifikasi serta mensintesiskan bukti-bukti untuk mendapatkan kesimpulan yang solid. ${ }^{5}$ Studi naskah memiliki dua sumber data, yaitu sumber data primer dan sumber data sekunder. Data primer adalah data otentik atau data langsung dari tangan pertama tentang masalah yang diungkapkan.

"Othman Llewelyn, "Fiqh al-Biah: Sumbangsih Syariah untuk Konservasi Lingkungan," dalam Colloqium on Islamic Fiqh On The Environment (Jakarta: UIN Syarif Hidayatullah, 2007), h. 21.

12 Benny Ridwan, "Kesadaran dan Tanggungjawab Pelestarian Lingkungan Masyarakat Muslim Rawa Pening Kabupaten Semarang", Inferensi: Jurnal Penelitian Sosial Keagamaan, 2 (Desember 2013), 326.

${ }^{13}$ Sutrisno Hadi, Motodologi Research, (Yogyakarta : Andi Offset, 1989), h. 9

14 Muh. Nadzir, Metode Penelitian, (Jakarta: Ghalia Indonesia, 1996). h. 62.

15 Sumadi Suryabrata, Metodologi Penelitian, (Jakarta: Raja Grafindo Persada, 1995), h. 16. 
Data ini disebut data asli. ${ }^{16}$ Sumber data primer yang dimaksud adalah Alquran, hadis, dan kitab kuning yang ada di pesantren. Data sekunder adalah data yang diperoleh atau dikutip dari sumber lain sehingga tidak bersifat otentik (tidak asli) karena diperoleh dari tangan kedua, ketiga dan seterusnya. ${ }^{17}$ Sumber data sekunder ini penulis gunakan sebagai data penunjang atau analisa perbandingan untuk mengetahui konsep ramah lingkungan menurut Alquran, hadis, dan kitab kuning di pesantren. Data tersebut harus dapat dipertanggung jawabkan validitasnya. Teknik analisis data dalam penelitian ini bersifat deskriptif, yaitu usaha untuk menginterpretasikan mengenai apa yang ada tentang kondisi, pendapat yang sedang berlangsung serta akibat (efek) yang terjadi atau kecenderungan yang tengah berkembang. ${ }^{18}$ Metode ini penulis gunakan untuk menginterpretasikan kitab kuning pesantren dan selanjutnya akan mengarah pada konsep ramah lingkungan dalam Alquran, hadis, dan kitab kuning di pesantren.

\section{Ramah Lingkungan dalam Perspektif Alquran, Hadis, dan Kitab Kuning di Pesantren}

Lima belas abad yang lalu, sebelum isu konservasi lingkungan menjadi wacana pemikiran, Nabi Muhammad telah menerima wahyu Alquran yang menjelaskan tentang tugas manusia sebagai khalifah di muka bumi, sebagaimana Firman Allah dalam surat al-Baqarah [2]: 30;

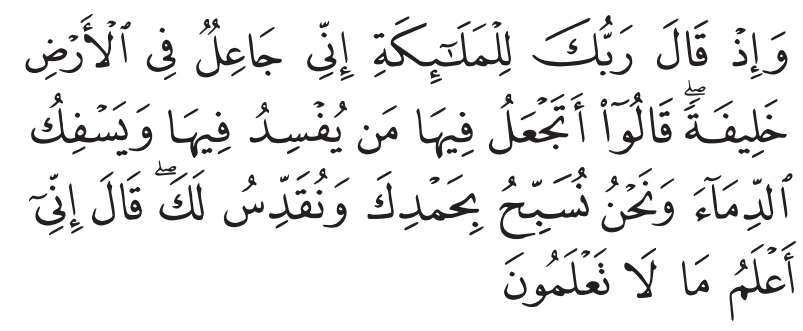

"Dan (ingatlah) ketika Tuhanmu berfrman kepada para malaikat, " Aku hendak menjadikan khalifah di muka bumi." Mereka berkata," Apakah Engkau hendak menjadikan orang yang merusak dan menumpahkan darah disana, sedangkan kami bertasbih memuji-Mu dan menyucikan nama-Mu?"

${ }^{16}$ Hadari Nawawi, Metodologi Penelitian Bidang Sosial, (Yogyakarta: Gajah Mada Press, 1995), h.. 80

${ }^{17}$ Hadari Nawawi, Metodologi Penelitian..., h. 81.

18 John W. Best, Research in Education, dalam Sanapiah Faisal dan Mulyadi Guntur Warseso (Peny.), Metodologi Penelitian Pendidikkan, ( Surabaya : Usaha Nasional, 1982), h. 119.
Dia berfirman,"Sungguh, Aku mengetahui apa yang tidak kamu ketahui." (Q.S. al-Baqarah [2]: 30)

Dalam tafsirnya, Imam Thabari menjelaskan bahwa manusia adalah khalifah (wakil Allah) di muka bumi. Walaupun di awal kejadiannya diragukan oleh malaikat, dengan mengatakan khalifah sebagai orang yang akan membuat kerusakan di muka bumi, namun Allah Swt memberikan jawaban bahwa Allah adalah Dzat yang paling mengetahui terhadap hal yang tidak diketahui oleh malaikat. Allah Swt meyakinkan malaikat, bahwa manusia bukan makhluk yang membuat kerusakan di muka bumi dengan memberikan kelebihan ilmu kepada nabi Adam $\mathrm{As}^{19}$.

Dengan ilmu, manusia menjadi khalifah di muka bumi. Tugasnya adalah sebagai penjaga agama dan pengelola bumi seisinya. Imam Mawardi dalam kitab al-Ahkâm al-Sulthâniyah menjelaskan bahwa tugas utama khalifah adalah menjaga ajaran agama sesuai dengan ajaran nabi Muhammad Saw, menjelaskan hujjah dan argumentasinya, serta menghadang para musuh agama. Selain itu, manusia sebagai khalifah juga memiliki tugas untuk mengelola urusan dunia, salah satunya adalah menjaga lingkungan hidup, konservasi hutan, dan pengelolaan tata kota $^{20}$.

Konservasi lingkungan merupakan tugas pokok manusia sebagai khalifah di muka bumi ini. Menjaga lingkungan sama dengan menjaga eksistensi manusia itu sendiri. Hubungan keduanya merupakan hubungan yang integratif yang tidak bisa dipisahkan satu dengan yang lain. Keduanya saling memanfaatkan satu sama lain dalam rantai kehidupan dan sistem ekologi. Dengan lingkungan hidup yang terjaga, maka makna lingkungan makin terasa manfaat dan maknanya bagi manusia dalam mempertahankan kelangsungan hidupnya ${ }^{21}$

Alquran secara tegas memerintahkan manusia untuk mengelola lingkungannya dengan baik, serta melarang untuk membuat kerusakan di muka bumi. Sebagaimana firman Allah dalam Alquran:

\footnotetext{
${ }^{19}$ Muhammad Ibnu Jarir At-Thobari, Jamiul Bayan fi Ta'wil Al Qur'an, (Beirut: Muassasah Ar Risalah, 2000) Jilid 1, h. 459.

${ }^{20}$ Imam Mawardi, al-Ahkam al-Sulthoniyah, (Kairo: Darul Hadis, t.t), h. 40.

${ }^{21}$ M. Bahri Ghazali, Lingkungan Hidup dalam Pemahaman Islam, (Jakarta: Pedoman Ilmu Jaya, 1996), h. 22-23.
} 


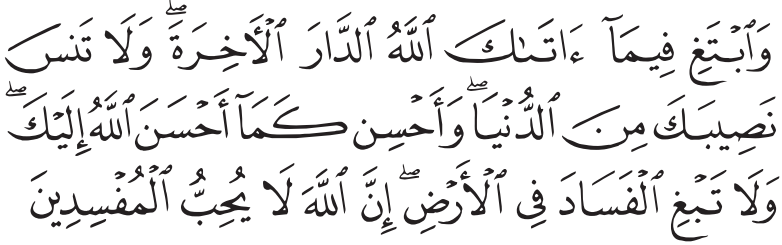

Dan carilah (pahala) negeri akhirat dengan apa yang telah dianugerahkan Allah kepadamu, tetapi janganlah kamu lupakan bagianmu di dunia dan berbuat baiklah (kepada orang lain),sebagaimana Allah telah berbuat baik kepadamu, dan janganlah kamu berbuat kerusakan di bumi. Sungguh, Allah tidak menyukai orang yang berbuat kerusakan. (Q.S. al-Qashash [28]: 77)

Imam Ibnu Katsîr memberikan penafsiran bahwa manusia diperintahkan Allah Swt untuk menggunakan segenap kemampuannya, baik moril maupun materil dalam beribadah kepada Allah Swt. Agar manusia mendapatkan pahala di dunia dan di akhirat. Selain itu, Allah memerintahkan manusia untuk tidak melupakan urusan dunia, seperti urusan makanan, sandang, perumahan dan lingkungan. Karena manusia memiliki hak kepada Allah, hak kepada diri sendiri, hak kepada keluarga, dan kepada lingkungannya. Oleh karena itu, setiap hak harus diberikan manusia sesuai dengan porsinya. Allah memerintahkan manusia untuk menjaga alam. Allah membenci manusia yang berbuat kerusakan di muka bumi, membuat kerusakan lingkungan dan alam ${ }^{22}$.

Dari beberapa keterangan di atas, penulis menemukan konsep ramah lingkungan yang terdapat dalam Alquran, hadis, dan kitab kuning, yaitu kewajiban manusia untuk menjaga terhadap lingkungan. Menjaga lingkungan menjadi tanggung jawab pokok manusia sebagai khalifah/wakil Allah di muka bumi. Allah secara jelas memerintahkan manusia untuk menjaga lingkungan dan melarang untuk membuat kerusakan di muka bumi.

Beberapa aplikasi konsep ramah lingkungan dalam Alquran, hadis, dan kitab kuning di pesantren adalah anjuran bagi setiap orang untuk melestarikan lingkungan dengan berbagai cara, yaitu:

${ }^{22}$ Abu al Fida' Ismail bin Umar bin Katsir, Tafsîr lbnu Katsîr (Beirut: Darul Kutub al Ilmiyah, t.t.), Jilid 6, h. 228.

\section{Menjaga Kebersihan}

Kebersihan merupakan hal yang pokok dalam ajaran kitab kuning pesantren, tujuannya untuk menjaga kebersihan diri, baik jiwa maupun raga. Kebersihan diri tidak akan tercapai tanpa kebersihan lingkungan dan alam sekitar. Sebagaimana yang disampaikan nabi Muhammad Saw ${ }^{23}$ :

$$
\text { السُطْهورُ شَطُرُ الإِيمَانِ }
$$

Kebersihan (kesucian) itu bagian dari Iman (HR. Muslim)

Menurut Imam An-Nawawi, maksud dari hadis di atas adalah perbuatan yang terkait dengan kebersihan dan kesucian seseorang merupakan bagian dari iman. Sedangkan makna dari sebagian dari iman, beberapa ulama berbeda pendapat, ada yang menyatakan bahwa pahala seseorang yang menjaga kebersihan dan kesuciannya mencapai pahala separuh dari iman. Ulama lain menjelaskan bahwa menjaga kebersihan dan kesucian itu menghapus terhadap kesalahan yang telah dilakukan, dengan syarat pelakunya beriman. Karena itu, kebersihan bagian dari iman ${ }^{24}$. Ulama lain menjelaskan bahwa maksud dari hadis di atas adalah salat itu bagian dari iman, sedangkan kebersihan (suci) menjadi syarat sah salat. Karena itu, kebersihan menjadi bagian dari iman.

Syarat sah orang yang salat adalah bersih (suci), baik badan, pakaian, maupun tempat yang dipakai salat. Kebersihan badan tidak akan sempurna tanpa kebersihan pakaian. Kebersihan pakaian tidak akan sempurna tanpa kebersihan tempat. Kebersihan tempat tidak akan sempurna tanpa kebersihan lingkungan. Kebersihan lingkungan tidak akan sempurna tanpa ada kebiasaan dan kesadaran masyarakat dalam menjaga kebersihan. Kebersihan badan, pakaian, tempat, dan lingkungan saling terhubung antara satu dengan yang lainnya. Dalam kaidah ushul fikih dijelaskan, bahwa jika sebuah kewajiban tidak sempurna tanpa instrumen yang menyempurnakan, maka instrumen penyempurna tersebut hukumnya wajib. Kewajiban membersihkan badan tidak akan sempurna tanpa membersihkan pakaian, maka

${ }_{23}$ Muslim bin Hajjaj, Shahih Muslim (Beirut: Dar Ihya Turats, tt), Jilid 1, h. 203.

24 Imam An- Nawawi, Al Minhâj Syarah Shahih Muslîm (Beirut: Dar Ihya Turats, t.t), Jilid 3, h. 100. 
hukum membersihkan pakaian hukumnya wajib. Kebersihan pakaian tidak akan sempurna tanpa kebersihan tempat, maka kebersihan tempat adalah wajib. Begitu juga, kebersihan tempat tidak akan tercapai tanpa kebersihan lingkungan, maka kebersihan lingkungan hukumnya adalah wajib. Dari beberapa argumen di atas, nilai yang diajarkan dalam kitab kuning pesantren adalah mendorong umat untuk menjaga kesucian dan kebersihan lingkungan.

Dalam kitab kuning, terdapat 17 mandi sunah untuk menjaga kebersihan, memakai wewangian, dan memakai pakaian yang bersih dan rapi $^{25}$. Di antaranya mandi ketika akan melaksanakan salat jumat, salat idul fitri, salat idul adha, dan mandi karena bau badan. tujuan disunnahkannya mandi adalah untuk menjaga kebersihan dan menghilangkan bau badan yang dapat mengganggu kenyamanan orang lain ${ }^{26}$. Bahkan dalam kitab kuning, terdapat dua hukum mandi demi menjaga kebersihan, yaitu wajib dan sunah. Perbedaannya, hukum mandi sunah adalah mandi yang dilakukan untuk menyambut kegiatan yang akan dilakukan, seperti dalam salat jumat, salat hari raya, dan lain sebagainya. Sedangkan mandi wajib adalah mandi yang dilakukan karena untuk membersihkan kotoran yang telah lalu. Seperti mandi junub, suci dari nifas, haid, dan lain sebagainya. ${ }^{27}$

\section{Menghidupkan Lahan Mati}

Memanfaatkan lahan mati dilakukan dengan menanami dan reklamasi serta menfungsikan lahan tersebut agar menjadi lahan yang produktif. Sebagimana disabdakan oleh Nabi Saw,

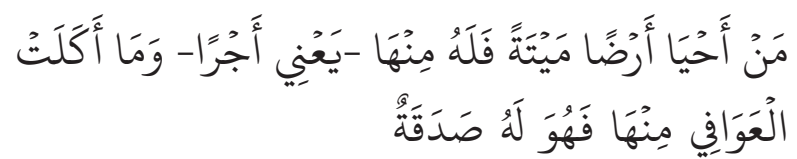

"Barangsiapa yang menghidupkan lahan yang mati/ terlantar maka ia memiliki bagian darinya, yakni (bagian) upah (dan atau pahala). Dan apa yang dimakan oleh binatang ternak dari (tanaman yang

${ }_{25}$ Abu Bakar Taqiyyuddin Al Syafi'i, Kifayatul Akhyar, (Damaskus: Darul Khoir, 1994),h. 45.

${ }^{26}$ Abdul Karim bin Muhammad Ar -Rofi'i Al -Quzwaini, Fathul Aziz Bisyarhil Wajiz (Beirut: Darul Fikr, t.t.), jilid 4, h. 615.

${ }_{27}$ Sulaiman bin Muhammad Al-Bujairomi, Hasyiyah Al Bujairomi Ala al Khotib (Beirut: Darul Fikr, 1995), jilid 1, h. 250. ada di lahan) itu, maka hal itu merupakan sedekah baginya" (HR Ahmad no. 14271 dan hadis ini shahih. Lihat Musnad Al Imam Ahmad ibn Hanbal, XXII/170, Muassasah Ar Risalah, Beirut, 1999).

Menurut Ibnu Hajar al-Asqalani, maksud dari menghidupkan lahan mati adalah memanfaatkan lahan yang tidak bertuan dengan irigasi, menanami, konservasi, maupun dengan bangunan. Jika tanah tersebut tidak bertuan, maka tanah tersebut otomatis menjadi milik orang yang mengelola ${ }^{28}$. Hal ini merupakan bentuk apresiasi ulama terhadap orang yang peduli terhadap lingkungan, sudah semestinya orang yang mau peduli terhadap lingkungan diberi apresiasi yang lebih, karena memiliki peran dalam pelestarian lingkungan hidup. Lingkungan hidup yang produktif akan membawa maslahat dan manfaat kepada ekologi alam sekitar, baik flora, fauna, maupun masyarakat sekitar.

Imam At-Thahawi berargumen, bahwa orang yang memanfaatkan lahan mati yang tak bertuan, otomatis akan menjadi pemiliknya, dianalogikan dengan air laut, air sungai, hewan dan burung buruan, ketika hal tersebut dimanfaatkan dan ditangkap oleh seseorang, otomatis hal tersebut menjadi miliknya yang sah secara syar' ${ }^{29}$. Pendapat ini menguatkan bahwa lahan mati yang tak bertuan akan menjadi milik sah orang yang memanfaatkannya, baik dengan cara menanami, menyirami, maupun memanfaatkannya demi kemaslahatan lingkungan hidup. Dari sini, penulis menilai bahwa ajaran kitab kuning pesantren mengajarkan kepada manusia untuk memanfaatkan lahan mati.

\section{Semangat Penghijauan}

Nabi Muhammad Saw dalam beberapa hadis memberikan motivasi kepada para sahabat dan kaum muslimin untuk menanam pohon dan melakukan penghijauan lingkungan, seperti sabda beliau:

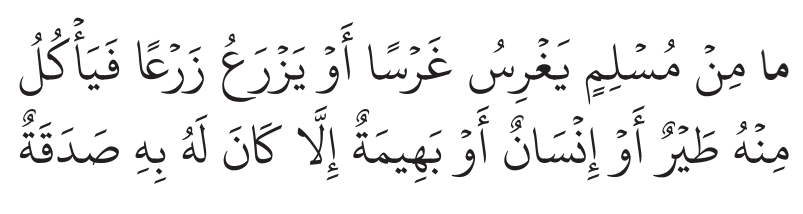

28 Ibnu Hajar Al-Asqalani, Fathul Bari, (Beirut: Darul Ma'rifah, t.t), Jilid 5, h. 18.

29 Ibnu Hajar Al-Asqalani, Fathul Bari..., h. 18 
"Tidaklah seorang muslim menanam suatu pohon atau bercocok tanam, lalu dimakan oleh burung atau manusia atau hewan kecuali baginya (pahala) sedekah karena itu" (HR. Bukhari no 2152 dan Muslim no. 2904).

Menurut Ibnu Bathol, hadis di atas memberikan motivasi kepada tiap Muslim untuk rajin menanam pohon, karena menanam pohon memiliki banyak manfaat bagi sistem ekologi, baik manfaat bagi manusia, bagi generasi masa depan, bagi hewan, maupun bagi alam ${ }^{30}$. Apalagi dengan kondisi saat ini, dengan krisis lingkungan, pemanasan global, dan pembalakan liar, melakukan penanaman pohon merupakan sesuatu yang amat dianjurkan oleh syariat agama, agar keseimbangan alam tetap terjaga dan kelangsungan ekosistem makhluk hidup tetap terjamin eksistensinya. Sedangkan menurut Muhammad Abdul Aziz Al-Syâdzilî, hadis di atas memberikan motivasi kepada tiap muslim untuk melakukan penghijauan demi kemaslahatan bersama, baik memberikan maslahat bagi manusia, lingkungan, maupun hewan sekitarnya ${ }^{31}$.

Tidak hanya itu, nabi Muhammad Saw memberikan semangat bercocok tanam dalam kondisi apapun, meski kiamat telah tiba. Hal tersebut dilakukan agar kelestarian lingkungan dan konservasi alam tetap terjaga. Nabi Saw bersabda:

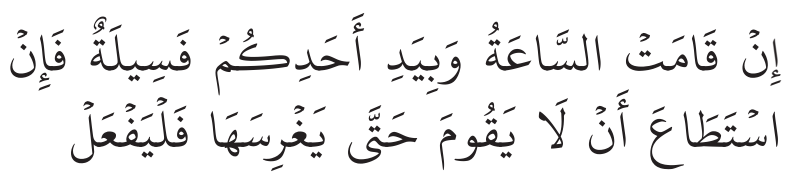

"Apabila kiamat telah datang dan di tangan salah seorang kalian sebuah ranting, jika ia dapat menanamnya maka lakukanlah" (HR. Ahmad no. 12981).

Hadis di atas memberikan motivasi kepada manusia untuk giat dalam menanam pohon, bahkan sebagian ulama menyatakan bahwa sebaik-baiknya pekerjaan adalah bercocok tanam. Pahala orang yang bercocok tanam akan selalu mengalir, baik di dunia maupun di akhirat. Hal tersebut diperkuat oleh Imam An-Nawawi, beliau menjelaskan bahwa selama pohon yang ditanam

${ }^{30}$ Ibnu Bathol, Syarah Shahih Bukhori (Riyadh: Maktabah Ar Rusydi, t.t), Jilid 6, h. 456.

${ }^{31}$ Muhammad Abdul Aziz Al-Syadzili, Al-Adab Al-Nabawi, (Beirut: Darul Ma'rifah, t.t), h. 36. masih eksis, termasuk buah dan kayunya, maka pahalanya akan tetap mengalir sampai hari kiamat. Inti dari hadis di atas adalah memberikan spirit penghijauan terhadap umat manusia, baik untuk kepentingan diri sendiri maupun generasi selanjutnya. Sehingga muncul sebuah kaidah: siapapun berbuat kebaikan, dan memberikan manfaat bagi lingkungan sekitarnya, pahalanya akan sampai kepada pelakunya. ${ }^{32}$

\section{Kawasan Konservasi (Hima)}

Kawasan konservasi adalah pembuatan kawasan yang dilindungi untuk kemaslahatan umum dan pengawetan habitat alami. Dalam kitab kuning, ditemukan sebuah hadis yang menunjukkan bahwa Nabi pernah membuat taman konservasi yang diperuntukkan untuk perlindungan kuda dan onta, seperti Hima An Naqi' untuk kuda dan onta sedekah yang telah diputuskan oleh Rasulullah Saw (sebagai pemimpin saat itu) di luar Madinah Al Munawwarah pada sekitar tahun 624-634 Masehi. Zaman sekarang hal ini dikenal dengan istilah kawasan konservasi. Sebagaimana hadis riwayat Imam Ahmad ${ }^{33}$ berikut:

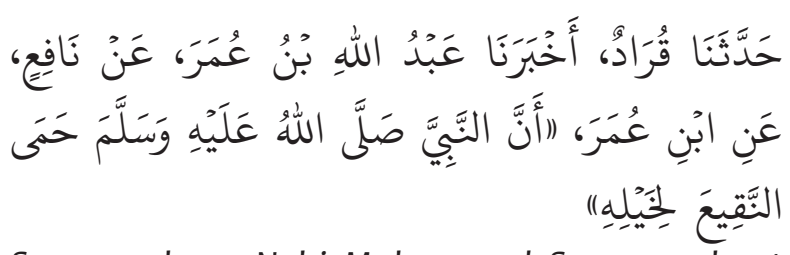

Sesungguhnya Nabi Muhammad Saw membuat kawasan konservasi tanah Naqi' untuk kuda Beliau.

Imam Syafi'i menjelaskan bahwa ada dua pendapat ulama tentang konservasi lingkungan hidup, pendapat pertama menyatakan bahwa tidak diperkenankan bagi siapapun untuk melakukan konservasi lingkungan, kecuali terhadap lahan yang telah ditentukan oleh nabi Muhammad Saw. Pendapat kedua, tidak diperkenankan bagi siapapun untuk melakukan konservasi lingkungan, kecuali sebagaimana lahan yang telah ditentukan oleh nabi Muhammad Saw. Pendapat pertama secara jelas menyatakan hanya Nabi yang dapat melakukan konservasi,

${ }^{32}$ Badruddin Al- Aini, Umdatul Qori Syarah Shohih Bukhori, (Beirut: Darul Ihya Turats, t.t), Jilid 12, h. 155.

33 Imam Ahmad bin Hanbal, Musnad Imam Ahmad bin Hanbal, (Beirut: Muassasah Risalah, 2001), Jilid 9,, h., 470. 
pendapat ini juga melarang selain Nabi untuk melakukan konservasi, termasuk pemerintah. Pendapat kedua sedikit lebih fleksibel, yaitu boleh bagi orang yang menduduki jabatan seperti nabi Muhammad, dalam hal ini adalah pemimpin daerah/wilayah.

Para ulama syafi'iyah lebih cenderung mengunggulkan pendapat yang kedua, dengan indikasi bahwa Sayyidina Umar bin Khattab juga melakukan konservasi lingkungan untuk menjaga unta shodaqoh dari kepunahan. Sebagaimana dalam atsar ${ }^{34}$ :

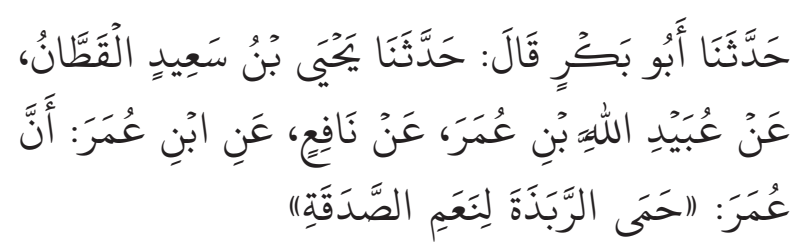

Dengan atsar di atas, ulama mengunggulkan pendapat kedua yang menyatakan bahwa konservasi lingkungan merupakan wewenang dari pemerintah, konservasi lingkungan dalam hal ini adalah melindungi lingkungan tertentu, berawal dari lahan untuk masyarakat umum menjadi lahan yang dilindungi oleh pemerintah, peruntukannya khusus untuk melindungi spesies tertentu, atau perlindugan terhadap kelestarian lingkungan. Sehingga tidak setiap orang dapat mengakses lahan tersebut. ${ }^{35} \mathrm{Hal}$ tersebut dilakukan karena demi kemaslahatan umum.

\section{Larangan Keras Mencemari Lingkungan}

Terdapat beberapa referensi yang menjelaskan larangan pencemaran lingkungan di tempat umum. Dalam hal ini termasuk larangan membuang limbah di sungai, membuang sampah di sembarang tempat, dan pencemaran udara. Karena pencemaran lingkungan dapat mengganggu terhadap ekosistem lingkungan. Sebagaimana sabda beliau ${ }^{36}$ :

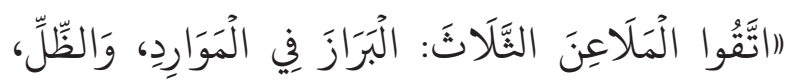

$$
\begin{aligned}
& \text { وَقَّارعَةِ الطَّرِيقِِ }
\end{aligned}
$$

${ }^{34}$ Abu Bakar bin Abi Syaibah, Al Mushonnaf, (Riyadh: Maktabah Ar Rusydu, 1988), Jilid 5, h. 6.

35 Imam Ahmad bin Hanbal, Musnad Imam Ahmad bin Hanbal (Beirut: Muassasah Risalah, 2001), Jilid 9, h. 470.

${ }^{36}$ Muhammad bin Ali Al-Syaukani, Nailul Author, (Mesir: Darul Hadis, 1993), Jilid 1, h. 112.
"Takutlah kalian tiga tempat yang dilaknat; buang air besar di tempat saluran air, naungan pohon (yang biasa digunakan untuk bernaung) dan jalanan umum" (HR Ibnu Majah, no. 328).

Dalam hadis di atas, siapapun dilarang untuk melakukan pencemaran pada tiga tempat, yaitu saluran air atau sungai, di bawah naungan pohon, dan jalan raya. Dalam hadis lain Nabi Saw bersabda ${ }^{37}$,

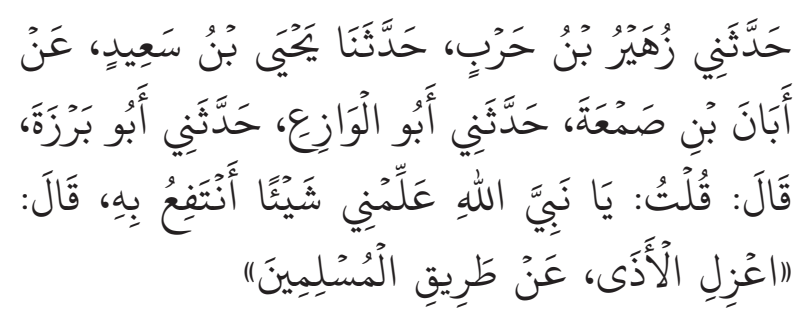

Hadis di atas menjelaskan bahwa umat Islam diperintahkan untuk menghilangkan kotoran dan sampah jalan, yang tentunya dapat meresahkan masyarakat ${ }^{38}$. seperti paku, sampah, duri, maupun butiran kawat dan besi. Karena hal tersebut dapat membahayakan terhadap pengguna jalan, seperti terjadinya kecelakaan atau minimal melukai pejalan kaki. Syariat sangat mengapresiasi terhadap orang yang mau membersihkan terhadap jalan raya. Dalam hadisnya Nabi bersabda ${ }^{39}$ :

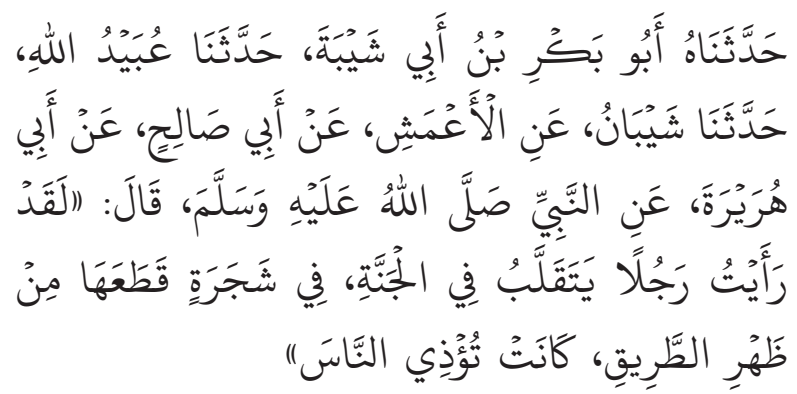

Hadis di atas menjelaskan bahwa pahala bagi orang beriman yang mau membersihkan kotoran di bahu jalan, yang mengganggu lingkungan masyarakat adalah mendapatkan surga. Lebih luas lagi, hadis ini juga menjadi pedoman bagi para pegiat lingkungan, karena tujuan mereka adalah untuk menjaga lingkungan dari kerusakan alam, yang tentunya mengganggu terhadap kehidupan manusia. Para pegiat lingkungan, yang tentunya dengan ikhlas menjaga lingkungan, akan

${ }^{37}$ Muhammad bin Ali Al Syaukani, Nailul Author..., h. 14.

38 Abu Hasan Ubaidillah, Muro'atul Mafatih Syarah Misykatul Mashobih, (India: Idarotul Buhuts IImiyah wal da'wah wal Ifta', 1984), Jilid 6, h. 340.

${ }^{39}$ Muslim bin Hajjaj, Shahih Muslim , (Beirut: Darul Ihya At Turatsi Al Arabi, t.t), Jilid 4, h. 20-21. 
mendapatkan surga di sisi Allah Swt.

Selain itu, dalam ajaran kitab kuning pesantren ditemukan ajaran yang mendorong untuk menjauhi kedhaliman, zalim adalah menempatkan sesuatu bukan pada tempatnya. Sebagaimana disampaikan Imam Mawardi ${ }^{40}$ :

$$
\text { الظلم هو وضع الشيء في غير محله }
$$

Secara syar'î, zalim adalah menggunakan sesuatu yang berkaitan dengan orang lain dengan tanpa kebenaran, atau menyimpang dari batasan syar'î. ${ }^{41}$ Berdasarkan hal di atas, perusak lingkungan, pembalak hutan, pembuang sampah dan limbah ke sungai, pembakar hutan dan lain lainnya merupakan perbuatan yang zalim dalam merusak lingkungan, membawa bencana bagi umat manusia, seperti banjir bandang, kabut asap, pemanasan global, dan tanah longsor ${ }^{42}$. Sehingga bagi mereka layak untuk mendapatkan sanksi berat atas prilaku mereka sendiri. Selain itu mereka wajib bertanggungjawab dan mengganti atas kerugian yang dialami orang sekelilingnya.

\section{Sanksi bagi Perusak Lingkungan}

Dasar dan pertimbangan diberlakukannya sanksi dalam kitab kuning pesantren, sebagaimana dalam kitab al-Tasyri' al-Jana'î adalah terjadinya kejahatan dan kerusakan yang berhubungan dengan masyarakat, baik terkait dengan etika, akidah, kehidupan individu, harta maupun moral kehidupan masyarakat. Hal di atas merupakan prinsip-prinsip yang terkait dengan kemaslahatan individu maupun kemaslahatan umum. Perbuatan yang berhubungan dengan kemasalahatan individu akan berimbas terhadap kemaslahatan umum. Karena itu, perbuatan yang merusak dihukumi haram karena untuk menjaga kemaslahatan umum. Sanksi dan hukuman yang diberikan atas perbuatan yang menyimpang, ditujukan untuk

${ }^{40}$ Abu Manshur Al-Maturidi, Tafsir Al Matûridî, (Beirut: Darul Kutub Al Ilmiyah, 2005), Jilid 2, h. 246.

${ }^{41}$ Muhammad Ali, Dalilul Falihin, (Beirut: Darul Ma'rifah, 2004), h. 514.

${ }_{42}$ Novianti Muspiroh, "Pendidikan Islam Berwawasan Lingkungan: Pendekatan Pembelajaran dan Desain Kurikulum", At-Tarbawi Jurnal Kajian Kependidikan Islam, 1 (Nopember, 2014), h. 63. menjaga kemaslahatan bersama ${ }^{43}$.

Pencemaran lingkungan itu terlarang karena tidak sesuai norma dan etika kehidupan, disamping karena keuntungan pribadi pelaku, seperti perbuatan membalak dan membakar hutan, membuang limbah di sungai, maupun merusak lingkungan, hal tersebut merupakan perbuatan yang tidak sesuai dengan etika dan norma kehidupan masyarakat, karena semua hal di atas merupakan perusakan lingkungan dan eksploitasi sumber daya alam demi keuntungan pribadi ${ }^{44}$. Hal tersebut merugikan terhadap kemaslahatan masyarakat, merusak lingkungan masyarakat, dan menganggu organisme kehidupan masyarakat. Berdasarkan hal tersebut, pembalakan hutan, pembakaran hutan, pembuangan limbah di sungai, dan polusi udara diharamkan demi menjaga tatanan kehidupan masyarakat, terutama untuk menyelamatkan lingkungan hidup.

Sanksi bagi perusak lingkungan merupakan instrument bagi terwujudnya konservasi lingkungan di masyarakat. Karena itu hukuman yang diberikan kepada perusak lingkungan adalah hukuman yang dapat memberikan efek jera bagi pelaku. Terdapat empat prinsip sanksi yang penting untuk diberikan terhadap pelaku pencemaran lingkungan. Pertama, sanksi yang dapat mendidik dan memberikan efek jera terhadap pelaku. Kedua, sanksi dapat menimbulkan rasa takut dan efek jera terhadap orang lain untuk melakukan pencemaran lingkungan. Ketiga, hukuman yang ditentukan bagi pelaku pencemaran disesuaikan dengan tindakan kejahatan yang dilakukan. Keempat, sanksi yang diberikan bersifat umum dan berimbang antara hukuman dan tindakan kejahatan yang dilakukan ${ }^{45}$.

Dari berbagai prinsip di atas, sanksi bagi perusak lingkungan disesuaikan dengan tindakan kejahatan yang dilakukan. Pelaku pembalakan dan pencurian hutan harus disesuaikan dengan hukuman pencurian, yaitu potong tangan. Pelaku pencemaran sungai yang mengakibatkan kerusakan alam dan menimbulkan penyakit

${ }^{43}$ Abdul Qodir Audah, Al Tasyri' Al Jana'i (Beirut: Darul Kutub Al'Arabi, tt), jilid 1, h. 384.

${ }^{44}$ Abdul Qodir Audah, Al Tasyri' Al Jana'i..., h. 384.

${ }^{45}$ Abdul Qodir Audah, Al Tasyri' Al Jana'i..., h. 384. 
bagi masyarakat dapat dihukum sesuai dengan hukuman penjara. Pelaku pembakaran hutan yang mengakibatkan hilangnya nyawa orang lain, dapat mendapatkan hukuman mati. Hukuman harus dilakukan seadil-adilnya tidak boleh tumpul ke atas dan tajam ke bawah. Semua kalangan dianggap sama di mata hukum ${ }^{46}$.

Beberapa ulama lebih tegas lagi, seperti Imam Malik, Imam Ahmad, dan beberapa Ashab Imam Syafi'i menjelaskan bahwa jika pelaku kerusakan berimbas pada hilangnya nyawa seseorang, pelaku bisa mendapatkan hukuman mati. Hal ini dilakukan karena para pembalak hutan, pembuang limbah, maupun perusak lingkungan dapat menyebabkan hilangnya nyawa orang lain, yaitu melalui tanah longsor, banjir, maupun penyakit asap yang diakibatkan oleh perusak lingkungan. ${ }^{47}$

\section{Urgensi Ramah Lingkungan dalam Perspektif Alquran, Hadis, dan Kitab Kuning di Pesantren}

Urgensi ramah lingkungan dalam perspektif kitab kuning pesantren adalah untuk kemaslahatan manusia dan alam raya. Maslahat adalah mengambil sebuah manfaat dan mengeliminir sebuah madarat ${ }^{48}$. Maslahat dirinci dalam lima aspek yaitu memelihara agama, jiwa, akal, keturunan, dan harta ${ }^{49}$. Kelima aspek ini berada pada peringkat yang berbeda bila ditinjau dari segi tujuannya yaitu peringkat dharûriyah (primer), hajiyyah (sekunder), dan tahsîniyyah (tertier). Dalam pandangan Izzuddin bin Abdissalam, maslahah memiliki makna kesenangan (lazzat) dan kebahagiaan (farah) dan sarana-sarana yang menjadi instrumennya. Maslahah dibagi menjadi dua kategori, yaitu maslahah duniawi dan maslahah ukhrawi. Yang pertama dapat diketahui dengan akal, yang kedua diketahui lewat Alquran dan hadis. Maslahah berbeda-beda tergantung level dan pendekatan yang dilakukan masyarakat. level maslahah paling rendah adalah maslahah

${ }^{46}$ Abdul Qodir Audah, Al Tasyri' Al Jana'i..., h. 384

47 Taqiyyudin Abu Abbas, As Siyasah As Syar'iyyah, (Saudi Arabia: Kementerian Islam dan Wakaf dan Dakwah, 1997), h. 93. ${ }^{48}$ Abdul Karim Zidan, Al Wajiz fi Ushul al-Fiqhi , (Beirut: Muassasah ar-Risalah, 1990), h. 236.

${ }^{49}$ Abdul Karim Zidan, Al Wajiz fi..., h. 379. untuk seluruh manusia ${ }^{50}$.

Dalam penelitian ini, maslahah menjadi metode istinbâth yang dapat dijadikan sebagai landasan berpikir dalam menjawab masalah lingkungan. Maslahah adalah usaha dan ikhtiar untuk mewujudkan kebaikan bagi seluruh alam dan menghindari kerusakan lingkungan. Ukuran maslahah adalah sejalan dengan prinsipprinsip syar'î ${ }^{51}$. Kedua tidak bersifat rekayasa kepentingan pribadi. Dan terakhir adalah maslahah tersebut menyangkut kepentingan orang banyak ${ }^{52}$.

Menjaga lingkungan dari kerusakan merupakan prinsip-prinsip yang sejalan dengan ajaran syar'î. Tujuannya demi keseimbangan alam dan menjamin keberlangsungan kehidupan umat manusia. Menjaga lingkungan di antaranya dapat dilakukan dengan banyak menanam pohon, mengurangi dampak rumah kaca, tidak membakar hutan dan menghindari polusi udara. Untuk meminimalisir pemanasan global yang dapat mengakibatkan kepunahan bagi umat manusia. Menurut keterangan dalam kitab kuning pesantren, menjaga lingkungan dan alam untuk keberlangsungan manusia merupakan sebuah kewajiban yang harus dilakukan secara mendesak. Karena meninggalkannya akan berakibat pada kerusakan alam dan lingkungan.

\section{Penutup}

Berdasarkan paparan diatas dapat disimpulkan sebagai berikut: Pertama, terdapat konsep ramah lingkungan dalam Alquran, hadis, dan kitab kuning di pesantren, yaitu manusia wajib menjaga lingkungan. Manusia sebagai khalifah Allah di muka bumi bertugas untuk menjaga agama dan menjaga lingkungan alam semesta. Kedua, formulasi ramah lingkungan dalam perspektif Alquran, hadis, dan kitab kuning pesantren adalah anjuran menjaga kebersihan, memanfaatkan lahan kosong menjadi produktif, semangat penanaman pohon dan penghijauan, membuat kawasan konservasi, larangan keras

\footnotetext{
50 Izzuddin bin Abdissalam, Qowaidul Ahkam, (Kairo: Istiqomah, t.t), h. 24.

${ }^{51}$ Abdul Karim Zidan, Al Wajiz fi..., h. 378

${ }^{52}$ Abu Rokhmat, "Fiqh Tanah untuk Kepentingan Publik”, International Journal Ihya' Ulumuddin, 1 (Juni, 2007), h. 75.
} 
mencemari lingkungan, dan sanksi berat bagi perusak lingkungan. Ketiga, urgensi ramah lingkungan adalah untuk kemaslahatan dan keberlangsungan jagad alam raya.

\section{Pustaka Acuan}

Abdillah, Mujiyono, Agama Ramah Lingkungan Perspektif Al-Qur'an, Jakarta: Paramadina, 2001.

Abdissalam, Izzuddin bin., Qowaidul Ahkam, Kairo: Istiqomah, t.t.

Abdullah, Amin, Falsafah Kalam di Era Postmodernisme, Yogyakarta: Pustaka Pelajar, 1995.

Abu Abbas, Taqiyyudin, As Siyasah As Syar'iyyah, Saudi Arabia: Kementerian Islam dan Wakaf dan Dakwah, 1997.

Aini, Badruddin, Al-,Umdatul Qori Syarah Shohih Bukhori, Beirut: Darul Ihya Turats, t.t.

Ali, Muhammad, Dalilul Falihin. Beirut: Darul Ma'rifah, 2004.

Asqolani, Al-, Ibnu Hajar, Fathul Bari, Beirut: Darul Ma'rifah, t.t.

Audah, Abdul Qodir, Al Tasyri' Al Jana'i, Beirut: Darul Kutub Al'Arabi, tt.

Bathol, Ibnu., Syarah Shahih Bukhori, Riyadh: Maktabah Ar Rusydi, t.t.

Bruinessen, Martin Van, Kitab Kuning: Pesantren dan Tarekat, Bandung: Mizan, 1994.

Bujairomi, Al-, Sulaiman bin Muhammad, Khasyiyah Al Bujairomi Ala al Khotib, Beirut: Darul Fikr, 1995.

Dhofier, Zamakhsari, Tradisi Pesantren: Studi Tentang Pandangan Hidup Kyai, Jakarta: LP3ES, 1983.

Ghazali, M. Bahri, Lingkungan Hidup dalam Pemahaman Islam, Jakarta: Pedoman Ilmu Jaya, 1996.

Hajjaj, Muslim bin, Shahih Muslim, Beirut: Dar Ihya Turats.

Hanbal, Imam Ahmad bin, Musnad Imam Ahmad bin Hanbal, Beirut: Muassasah Risalah, 2001.

Ibrahim, Rustam, Bertahan di Tengah Perubahan: Pesantren Salaf, Kiai, dan Kitab Kuning, Jogjakarta: Sibuku kerjasama dengan UNU Surakarta, 2015.
Katsir, Abu al Fida' Ismail bin Umar bin, Tafsir Ibnu Katsir, Beirut: Darul Kutub al IImiyah, t.t.

Llewelyn, Othman, "Fiqh al-Biah: Sumbangsih Syariah untuk Konservasi Lingkungan," dalam Collogium on Islamic Figh On The Environment, Jakarta: UIN Syarif Hidayatullah, 2007.

Maturidi, Abu Manshur, Al-, Tafsir Al Maturidi, Beirut: Darul Kutub Al Ilmiyah, 2005.

Mawardi, Imam, al-Ahkam al-Sulthoniyah, Kairo: Darul Hadis, t.t.

Muhammad dkk, Ahsin Sakho. (Ed), Fikih Lingkungan, Laporan Indonesia Forest and Media Campaign (Inform): Pertemuan Menggagas Fikih Lingkungan oleh Ulama Pesantren di Lido Sukabumi, 9-12 Mei 2014.

Muspiroh, Novianti, "Pendidikan Islam Berwawasan Lingkungan: Pendekatan Pembelajaran dan Desain Kurikulum", AtTarbâwi Jurnal Kajian Kependidikan Islam, 1. Nopember, 2014.

Nawawi, Imam, An-, Al Minhaj Syarah Shahih Muslim. Beirut: Dar Ihya Turats, t.t.

Quzwaini, Abdul Karim bin Muhammad Ar Rofi'l, Al-, Fathul Aziz Bisyarhil Wajiz. Beirut: Darul Fikr, t.t.

Ridwan, Benny, Kesadaran dan Tanggungjawab Pelestarian Lingkungan Masyarakat Muslim Rawa Pening Kabupaten Semarang, Inferensi: Jurnal Penelitian Sosial Keagamaan, 2. Desember, 2013.

Rokhmat, Abu, "Fiqh Tanah untuk Kepentingan Publik”, International Journal Ihya' Ulumuddin, 1. Juni, 2007.

Syadzili, Muhammad Abdul Aziz, Al-, Al-Adab AlNabawi, Beirut: Darul Ma'rifah, t.t.

Syafi'i, Abu Bakar Taqiyyuddin, Al-, Kifayatul Akhyar, Damaskus: Darul Khoir, 1994.

Syaibah, Abu Bakar bin Abi, Al Mushonnaf, Riyadh: Maktabah Ar Rusydu, 1988.

Syaukani, Al, Muhammad bin Ali, Nailul Author, Mesir: Darul Hadis, 1993.

Thobari, Muhammad Ibnu Jarir, At- Jamiul Bayan fi Ta'wil Al Qur'an, Beirut: Muassasah Ar Risalah, 2000. 
Ubaidillah, Abu Hasan, Muro'atul Mafatih Syarah Misykatul Mashobih, India: Idarotul Buhuts Ilmiyah wal da'wah wal Ifta', 1984.

Umar, Hasbi, Nalar Fiqih Kontemporer, Jakarta: GP Press, 2007.
Wahid, Abdurrahman, “Asal-Usul Tradisi Keilmuan di Pesantren”, Jurnal Pesantren. Januari,1984.

Zidan, Abdul Karim, Al Wajiz fi Ushul al-Fiqhi, Beirut: Muassasah ar-Risalah, 1990. 